\title{
TOXICITY ASSESSMENT OF AFRICAN LOCUST BEAN EFFLUENTS ON AGRICULTURAL SOIL AND AQUATIC ORGANISM AT JIMBA- OJA AND TEMIDIRE LOCUST BEAN (Parkia biglobosa) PROCESSING CENTERS
}

\author{
${ }^{1}$ Amusat, M. A., ${ }^{2}$ Ayeloja, A. A., ${ }^{3}$ Dada-Joel, O. T. and ${ }^{1}$ Eneh, K. C. \\ ${ }^{1}$ Department of Processing and Storage Engineering, National Centre for Agricultural Mechanization, P M B 1525, \\ Ilorin, Nigeria \\ ${ }^{2}$ Department of Aquaculture and Fisheries, University of Ilorin, P M B 1515, Ilorin, Nigeria \\ ${ }^{3}$ Department of Farm Power and Machinery, National Centre for Agricultural Mechanization, P M B 1525, Ilorin, \\ Nigeria \\ Corresponding author's email: amusat_abiodun@yahoo.com \\ (Received: 8th November, 2019; Accepted: 11th February, 2020)
}

\section{ABSTRACT}

\begin{abstract}
Indiscriminate processing of agricultural produces has led to the alteration of agricultural soil and aquatic habitat, consequently threatening food security, human health and natural population size of aquatic organisms. This study investigated chemical properties of the soil at Jimba-Oja and Temidire locust bean(Parkia biglobosa) processing centres. The static bioassays were also performed on Clarias gariepinus to evaluate the median lethal concentrations of the locust bean effluents within 72 and 96 hours. Physico-chemical parameters of effluents showed that $\mathrm{pH}$ was slightly acidic (6.44 to 6.73 respectively). The dissolved oxygen ranged from 6.48 to 6.73 $\mathrm{mg} / \mathrm{L}$ and phosphate from 67.52 to $82.60 \mathrm{mg} / \mathrm{L}$. The concentration of copper, iron, nickel ranged from 6.77 to $8.84,32.57$ to 47.67 and 0.21 to $1.04 \mathrm{mg} / \mathrm{L}$ respectively. These parameters exceeded the Federal Environmental Protection Agency (FEPA) permissible limits. The Effluents from Parkia biglobosa impacted soil with high concentrations of heavy metals ranging from: copper 4.72 to 5.02 , cadmium 0.03 to 0.35 , iron 51.82 to 76.41 and nickel 0.13 to 0.05 at processing centers compared to the control site. Toxicity assessments indicated that the mortality increased with increase in effluent concentration. $\mathrm{LC}_{50}$ tests (36\%:72 hours), (20\%: 96 hours), (30.1\%: 72 hours) and (20\%: 96 hours) concentrations were carried out for Jimba-oja and Temidire respectively and the sublethal dose of below $7.5 \%$ for both Parkia biglobosa processing centers were obtained. The study concluded that releasing Parkia biglobosa effluent to the environment have negative impacts on agricultural soil and aquatic organisms. There is therefore need for relevant government agencies to control indiscriminate discharge of these effluents into the environment untreated.
\end{abstract}

Keywords: Locust bean effluent, Toxicity, Agric soil, Aquatic Organism

\section{INTRODUCTION}

African locust bean is a leguminous plant which has as an outstanding amino acid composition and protein quality (Alabi et al., 2003; Elemo et al., 2011). It is called Iru in southwestern Nigeria and dawadawa in Ghana (Ojewumi et al. 2016b). Parkia biglobosa is well known for its high commercial values as food and medicinal substance, it is also used as a flavour intensifier for soups and stews (Dike and Odunfa, 2003). In Nigeria, the rapid growth in population has lead to increase in the demand for $P$. biglobosa which has led to establishment of many processing centres where both traditional and mechanical methods of processing where adopted. National Centre for Agricultural Mechanization is a potential prototype of $P$. biglobosa processing industry. Contamination of agricultural soils and aquatic environments due industrial effluent discharge has always been an issue which is considered as a critical challenge in ecosystem (Faruk et al., 2006). The dried fruit pods of $P$. biglobosa contains heavy metals (Henry et al., 2016), heavy metals are dangerous because they tend to bioaccumulate in soil, water and air which are taken up by the roots and foliage, they have potential hazardous effect not only on plants and aquatic animals but also on human health (Das et al., 1997) depending on the dose and duration of exposure (Yusuff and Sonibare, 2004). The other toxic aspects of the plant identified to contain piscicidial properties comprise the bark, pods, fresh seeds and the pulp (Bonkoungou, 1986) and this plant has also been known to contain alkaloids and tannins (Akintobi et al., 2016), The Plant is also poisonous to fish (Fafioye et al., 2005). In Nigeria agricultural practices along river banks includes washing of pods of $P$. biglobosa off the seeds for Iru or 
dawadawa processing which could lead to a buildup of toxic chemical in fresh water, causing mass mortality of fish and affecting non-target organisms (Ayoola, 2008). Toxicity study is an important part of ecotoxicological studies which aid to find out toxicant limit and its safe concentration, so that there would be less harm to aquatic fauna. The reduction in water quality as a result of alteration of aquatic environment by physical and chemical changes often cause some physiological changes in fish, thus it determines the productivity and fish survival. Most of our natural water resources are gradually over polluted at an alarming rate due to human exogenous activities Including the discharge of toxic organic matter of plants, land surface washing, industrial and sewage effluents discharge etc (Karnataka State Pollution Control Board, 2002). Excessive accumulation of heavy metals in agricultural soils and farm produces through wastewater irrigation may result in soil contamination and can also affect food quality and safety (Amusat et al., 2018). This research aim at investigating the environmental impact of African locust bean effluent discharge on agricultural soil and its effects on aquatic organisms.

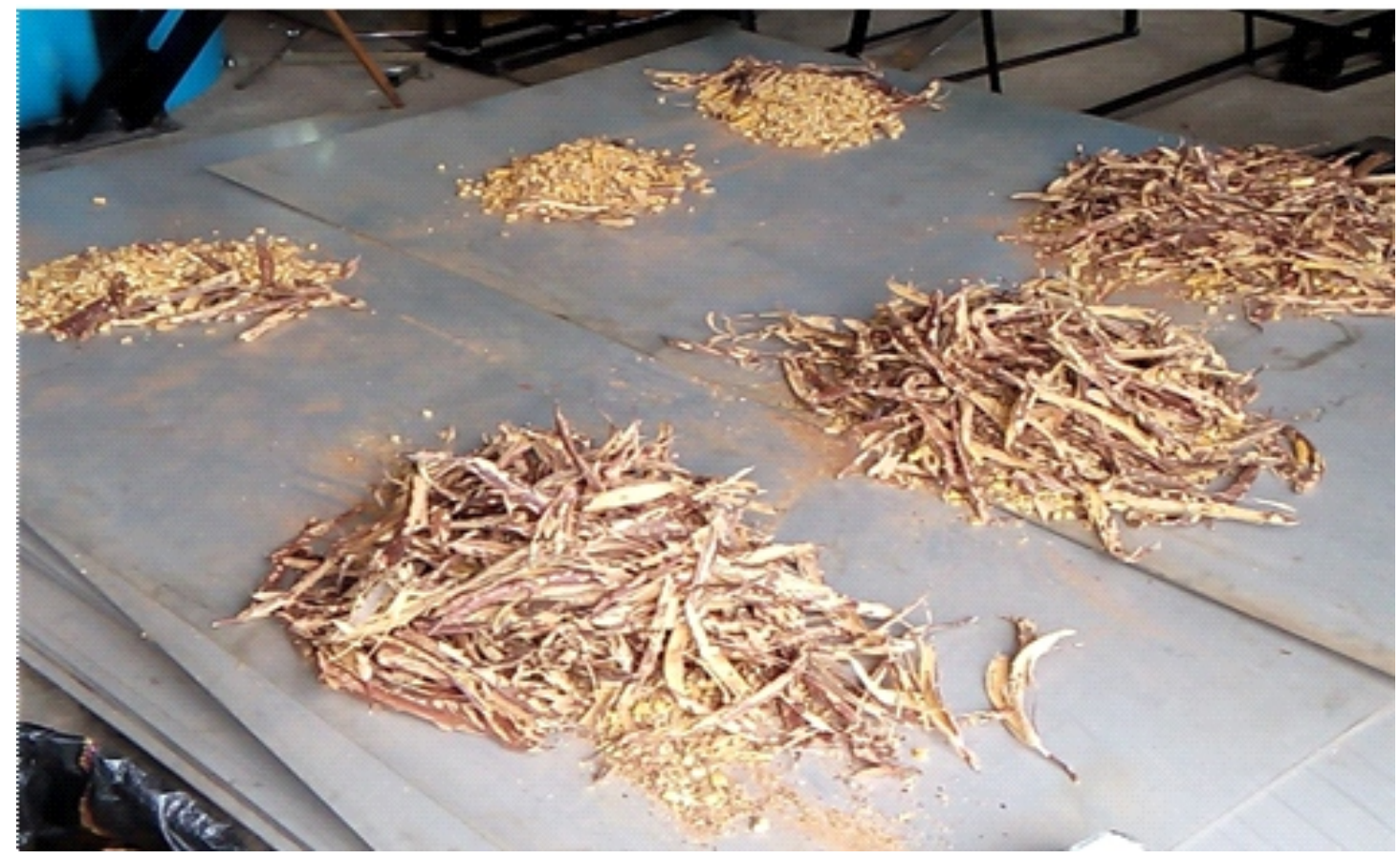

Fig. 1: Pod and fruit pulp of African locust bean

\section{MATERIALS AND METHODS The study areas}

Jimba-oja and Temidire African locust bean processing locations are among the major processing centres of African locust bean located in Ilorin, Kwara State, North central of Nigeria.

Jimba-oja African locust bean processing centre located Latitude $819^{\prime} 56^{\prime \prime} \mathrm{N}$ and Longitude $4^{\circ} 39^{\prime}$ $52 " \mathrm{E}$ in Ifelodun local government area, outskirt Ilorin town. Temidire processing centre located Latitude $8^{\circ} 24^{\prime} 54^{\prime \prime} \mathrm{N}$ and Longitude $4^{0} 34^{\prime} 53^{\prime \prime} \mathrm{E}$ in Ilorin central local government. Temidire/Babaode river flows through Temidire community and is among the tributaries of a popular Asa River in Ilorin metropolis. 


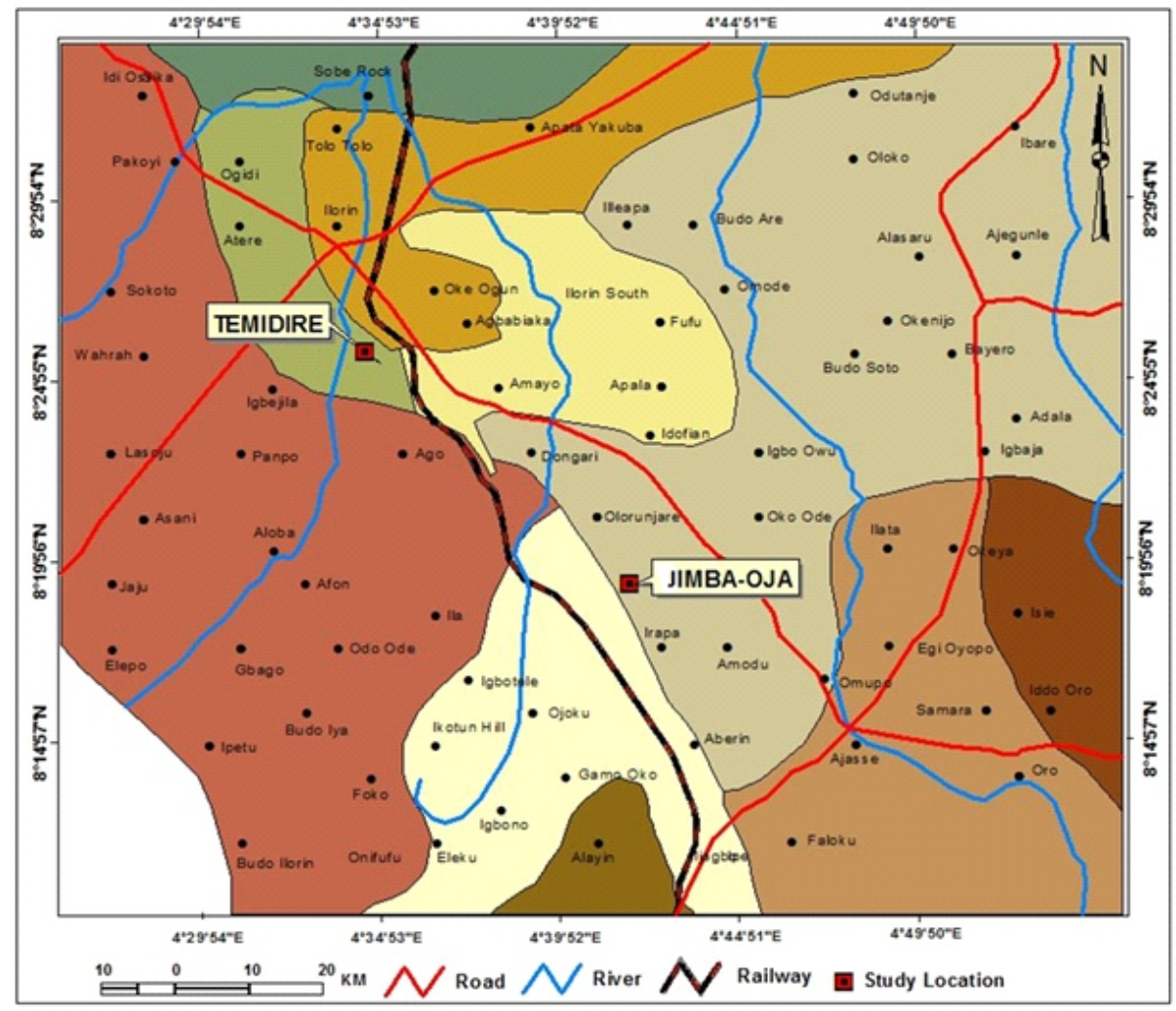

Fig. 2: Map of the study locations

\section{Samples collection}

Locust bean effluent samples were collected from the two African locust bean processing centres (Jimba-oja and Temidire) into kegs and transported to National Centre for Agricultural Mechanization's Integrated Farm Project for fish culture while the required volume were taken from the effluent samples to laboratory for physicochemical analyses.

Similarly, soil sample was collected from each African locust bean processing centre using Shiprek branded soil auger disinfected with cotton wool soaked in $70 \%$ ethanol at $0-15 \mathrm{~cm}$ depth. Four soil samples were collected 1 meter away from all sides of the processing centre for a particular location while the sample adjacent to the locust bean processing centre served as control. Clear and sterilize amber coloured glass bottles, rinsed thrice in distilled water solution was used to keep the soil samples prior routine physico-chemical analysis. The concentrations of copper, cadmium, lead, nickel and iron in the soil samples were analysed.

\section{Sample analysis}

Selected physico-chemical parameters of the locust bean effluent were evaluated either in situ or ex situ. The parameters evaluated in situ are: colour, $\mathrm{pH}$ and temperature. Electronically combined pH meter (Combo HI 98130, Hanna, USA) was used for in situ evaluation of the effluent which was first diluted and neutralize with distilled water and then dipping its probe into the effluent to take readings.

The physico-chemical parameters that were determined in the laboratory using APHA (1995) are: total hardness, dissolved oxygen, phosphate, nitrate and sulphate. The heavy metals concentrations of copper, cadmium, nickel, iron and lead in the locust bean effluent samples were also analysed using atomic Absorption Spectrophotometer after digestion with $12 \mathrm{ml}$ of conc. $\mathrm{HNO}_{3}$ and $4 \mathrm{ml}$ of conc. $\mathrm{HCl}$ (3:1) in accordance to aqua regia method.

\section{Fish collection}

Fingerlings of Clarias gariepinus (2300 pieces) used for this investigation were collected from National Centre for Agricultural Mechanization's Integrated Farm Project and transported to the 
laboratory in large aerated polythene bags containing freshwater from the farm pond. Only healthy and active Clarias gariepinus of Mean Total Length average $(10.3 \pm 1.02 \mathrm{~cm}$ length) and (weight $12.2 \pm 2.1 \mathrm{~g}$ ) were randomly selected for the toxicity observation.

Healthy fish were placed in large aquarium of 25 liter capacity with well aerated borehole water. Prior to this, the aquaria were washed with potassium permanganate solution. The fish were allowed to acclimatize to the environmental conditions for period of two weeks before the experiment. Water in each aquaria was changed at three days interval to prevent accumulation of the metabolic wastes. During the period of acclimatization the fish were fed twice daily with fish meal at $3 \%$ body weight in accordance with (Olaniyi and Salau, 2013). Feeding was discontinued 24 hours prior to the commencement of the experiment.

\section{Toxicity Evaluation}

Ten fish were stocked per aquarium containing five varying concentrations of locust bean effluent in three replicate $(7.5,15,20,50$ and $75 \%)$ mixing with well aerated 20 liters borehole water. The control experiment was similarly set up in three replicate. The experiment was conducted to determine the toxicity in the different concentrations for 72 and 96 hours of exposure. The test organisms were observed for behavioral responses and mortalities at these hours. Dead fish were removed from test solutions as soon as observed. A fish was considered dead when it was completely immobile with no respiratory and tail movements.

\section{Statistical Analysis}

The results obtained were subjected to $T$ test and one way ANOVA at $\mathrm{p}<0.05$ level of significance using SPSS version 16.0 for Windows.

\section{RESULTS AND DISCUSSION}

Table 1 shows the result of the independent t-test used to compare the mean values of physicochemical parameter of Jimba-Oja and Temidire African locust bean effluent.

The mean of temperature, $\mathrm{pH}$, dissolved oxygen (DO), total hardness, phosphate, nitrate, iron and nickel from Jima- Oja effluent are not significantly different from that of Temidire effluent at $5 \%$ level of significance. The mean value of sulphate, copper and nickel from the two locations are significantly different.

The locust bean effluent from Jinba-Oja and Temidire was dark brown and black in appearance respectively with objectionable odours. The variation in the physico-chemical parameters of the two Africa locust bean effluent types collected from each of the processing center under the study shown (Table 1), that there were considerable difference in physico-chemical parameters of effluent and chemical properties of the soil between locations, the difference in parameters suggests to the nature and types of the soil that produced each of the Africa locust bean. The physico-chemical parameters show that the effluents accumulation might be of negative impact to aquatic organisms if it is continually released to the environment and ends up in rivers. The reason is that some of these parameters specifically, phosphate, copper, iron, nickel and dissolved oxygen in both locations were above the standard specification for maximum limit allowed for effluent released into water bodies (FEPA, 1991).

The mean concentration of copper, cadmium, iron, lead and nickel in the soil samples from the study locations and control site were significantly different as shown in Table 2 .

The soil concentration of copper was between the ranges $4.72-5.02 \mathrm{mg} / \mathrm{kg}$. Recommended limit by Dutch standard is $36 \mathrm{mg} / \mathrm{kg}$. All the soil samples are within the permissible limit.

The concentration of cadmium in the soil samples from the two locations were found in the range of 0.03 to $0.35 \mathrm{mg} / \mathrm{kg}$ in the soil. The values were below the maximum limit of cadmium in the soil recommended by Dutch standard $(0.8 \mathrm{mg} / \mathrm{kg})$ while cadmium was not detected at the control site.

The concentration of iron ranged from 51.82 $\mathrm{mg} / \mathrm{kg}$ to $76.14 \mathrm{mg} / \mathrm{kg}$ were within permissible limit. The maximum allowable limit of iron is 150 $\mathrm{mg} / \mathrm{kg}$ WHO (1996).

The concentration of lead in soil samples from the 
two locations were below the detection limit.

The concentration of nickel in soil samples was between $0.05-0.13 \mathrm{mg} / \mathrm{kg}$. Recommended limit for nickel by WHO 1996 is $35 \mathrm{mg} / \mathrm{kg}$. The values were below this recommended limit.

Table1: Fysico-chemical parameters of locust bean effluents

\begin{tabular}{|c|c|c|c|c|c|c|c|c|}
\hline Parameter & Location & $\mathrm{T}$ & Df & Sig. & Mean & $\mathrm{MD}$ & SE (MD) & $\begin{array}{c}\text { FEPA } \\
\text { Standard }\end{array}$ \\
\hline \multirow[t]{2}{*}{ Temperature } & Jimba-oja & 2.97 & 4.00 & 0.041 & 26.59 & 0.99 & 0.33 & $35^{\circ} \mathrm{C}$ \\
\hline & Temidire & 2.97 & 3.98 & 0.041 & 25.60 & 0.99 & 0.33 & \\
\hline \multirow[t]{2}{*}{$\mathrm{pH}$} & Jimba-oja & 4.065 & 4.00 & 0.015 & 6.44 & 0.29 & 0.07 & $6 \sim 9$ \\
\hline & Temidire & 4.065 & 3.00 & 0.027 & 6.73 & 0.29 & 0.07 & \\
\hline \multirow[t]{2}{*}{ DO } & Jimba-oja & 0.848 & 4.00 & 0.444 & 6.48 & 0.10 & 0.12 & 5 \\
\hline & Temidire & 0.848 & 3.99 & 0.444 & 6.59 & 0.10 & 0.12 & \\
\hline \multirow[t]{2}{*}{ Total hardness } & Jimba-oja & 4.211 & 4.00 & 0.014 & 483.33 & 20.00 & 4.74 & N/A \\
\hline & Temidire & 4.211 & 3.95 & 0.014 & 503.33 & 20.00 & 4.74 & \\
\hline \multirow[t]{2}{*}{ Sulphate } & Jimba-oja & 2.772 & 4.00 & 0.050 & 3.06 & 0.45 & 0.16 & 100 \\
\hline & Temidire & 2.772 & 3.97 & 0.051 & 2.61 & 0.45 & 0.16 & \\
\hline \multirow[t]{2}{*}{ Phosphate } & Jimba-oja & 5.405 & 4.00 & 0.006 & 82.60 & 15.08 & 2.79 & 50 \\
\hline & Temidire & 5.405 & 3.17 & 0.011 & 67.52 & 15.08 & 2.79 & \\
\hline \multirow[t]{2}{*}{ Nitrate } & Jimba-oja & 7.847 & 4.00 & 0.001 & 2.65 & 0.83 & 0.10 & 75 \\
\hline & Temidire & 7.847 & 2.07 & 0.014 & 1.82 & 0.83 & 0.10 & \\
\hline \multirow[t]{2}{*}{ Copper } & Jimba-oja & 0.131 & 4.00 & 0.902 & 6.77 & 0.07 & 0.53 & $<1$ \\
\hline & Temidire & 0.131 & 2.44 & 0.906 & 6.84 & 0.07 & 0.53 & \\
\hline \multirow[t]{2}{*}{ Cadmium } & Jimba-oja & 1.265 & 4.00 & 0.275 & 0.18 & 0.02 & 0.02 & $<1$ \\
\hline & Temidire & 1.265 & 3.44 & 0.285 & 0.15 & 0.02 & 0.02 & \\
\hline \multirow[t]{2}{*}{ Iron } & Jimba-oja & 7.586 & 4.00 & 0.002 & 47.67 & 15.09 & 1.98 & 0.3 \\
\hline & Temidire & 7.586 & 3.00 & 0.005 & 32.57 & 15.09 & 1.98 & \\
\hline \multirow[t]{2}{*}{ Nickel } & Jimba-oja & 14.305 & 4.00 & 0.000 & 1.04 & 0.83 & 0.05 & 0.02 \\
\hline & Temidire & 14.305 & 2.16 & 0.003 & 0.21 & 0.83 & 0.05 & \\
\hline
\end{tabular}

$\mathrm{MD}$ is mean difference, $\mathrm{SE}$ is standard error

FEPA is Federal Environmental Protection Agency

N/A is not available

Table 2: Chemical properties of the soil of the effluent collection sites. Parameters

\begin{tabular}{lccccc|} 
Effluent locations & $\mathbf{C u}(\mathbf{m g} / \mathbf{k g})$ & $\mathbf{C d}(\mathbf{m g} / \mathbf{k g})$ & $\mathbf{F e}(\mathbf{m g} / \mathbf{k g})$ & $\mathbf{P b}(\mathbf{m g} / \mathbf{k g})$ & $\mathbf{N i}(\mathbf{m g} / \mathbf{k g}$ \\
\hline Jimba-oja & $5.02 \pm 0.02^{\mathrm{a}}$ & $0.35 \pm 0.04^{\mathrm{a}}$ & $76.41 \pm 1.42^{\mathrm{a}}$ & $<0.001 \pm 0.0$ & $0.13 \pm 0.12^{\mathrm{a}}$ \\
Temidire & $4.72 \pm 0.13^{\mathrm{b}}$ & $0.03 \pm 0.01^{\mathrm{b}}$ & $51.82 \pm 2.01^{\mathrm{b}}$ & $<0.001 \pm 0.0$ & $0.05 \pm 0.01^{\mathrm{b}}$ \\
Control Mean & $0.362 \pm 0.21^{\mathrm{c}}$ & $<0.001 \pm 0.0$ & $31.06 \pm 0.15^{\mathrm{c}}$ & $<0.001 \pm 0.0$ & $<0.001 \pm 0.0$ \\
\hline
\end{tabular}

Mean values along the columns with different superscripts were significantly different $(p<0.05)$.

The observations in this study regarding to significant variation of heavy metals compare to the control means of agricultural soil (Table 2) presents the extent and rate at which locust bean wastewater impacted soil. The bark, pods and fresh seeds of Africa locust beans is known to contain heavy metals and piscicidial properties (Bonkoungou, 1986; Akintobi et al., 2016; Henry et al., 2016). These boiling or fermentation processes to which the seeds are subjected to could increase the discharge of these harmful effluents to the agricultural soil and could lead to plant uptake of heavy metals from soil at high concentrations greater than optimal values (Amusat et al., 2018), this may result in a great health risk taking into consideration food-chain implications.

Tables $3-6$ shows the test conducted to evaluate the toxicity of Africa locust bean effluent on 
Clarias gariepinus. During the toxicity study, the exposure of C. gariepinus to varying concentration of locust bean effluent samples from the two locations caused noticeable and significant behavioural alterations such as loss of reflexes, skin decolouration, restlessness, loss of equilibrium, erratic swimming, babel deformation and cluster of mucus were observed among the fish which was unnoticeable in the control sample. The direct proportionality increase in behavioural alterations with increase in the concentrations of the effluents were recorded, especially in fish exposed to highest concentration $(50 \%$ and 75 $\%$ ). The injuries effluent caused possibly weaken the fish's resistance to contaminant and thus result in death of $50 \%$ individuals at the highest concentration exposures. This could be attributed to the presence of nitrate and sulphate in effluent which can form acidic products (Odeyemi et al., 2000) and cumulative impact of heavy metals present in the effluent.

Table 3: Nmber of death at 72 hens far Jiba-cin efineat

\begin{tabular}{|c|c|c|c|c|c|c|c|c|}
\hline \multirow[b]{2}{*}{ Conc. of effluent (\%) } & \multirow[b]{2}{*}{ 1(Freq.) } & \multicolumn{5}{|c|}{ Replicates } & \multirow[b]{2}{*}{ Total mortalities } & \multirow[b]{2}{*}{$\%$ mortality } \\
\hline & & Pct. & 11(Freq.) & Pct. & 111(Freq.) & Pct. & & \\
\hline Control & 0 & 0 & 0 & 0 & 0 & 0 & 0 & 0 \\
\hline 7.5 & 2 & 20 & 3 & 30 & 2 & 20 & 7 & 23.3 \\
\hline 15 & 3 & 30 & 4 & 40 & 3 & 30 & 10 & 33.3 \\
\hline 20 & 4 & 40 & 4 & 40 & 5 & 50 & 13 & 43.3 \\
\hline 50 & 5 & 50 & 7 & 70 & 5 & 50 & 17 & 56.7 \\
\hline 75 & 8 & 80 & 7 & 70 & 10 & 100 & 25 & 83.3 \\
\hline
\end{tabular}

Table 4: Number of death at 96 hours for Jimba-oja effluent

\begin{tabular}{|c|cccccc|cc|}
\hline \multicolumn{7}{|c|}{ Replicates } \\
Conc. of effluent (\%) & 1(Freq.) & Pct. & 11(Freq.) & Pct. & 111(Freq.) & \multicolumn{1}{c|}{ Pct. } & Total mortalities \% mortality \\
\hline Control & 0 & 0 & 0 & 0 & 0 & 0 & 0 & 0 \\
7.5 & 4 & 40 & 3 & 30 & 3 & 30 & 10 & 33.3 \\
15 & 5 & 50 & 4 & 40 & 4 & 40 & 13 & 43.3 \\
20 & 6 & 60 & 5 & 50 & 4 & 40 & 15 & 50 \\
50 & 8 & 80 & 7 & 70 & 6 & 60 & 21 & 70 \\
75 & 10 & 100 & 8 & 80 & 9 & 90 & 27 & 90 \\
\hline
\end{tabular}

Table 5: Number of death at 72 hours for Temidire effluent

\begin{tabular}{|c|cccccc|cc|}
\hline & \multicolumn{7}{|c|}{ Replicates } & \\
Conc. of effluent (\%) & 1(Freq.) & Pct. & 11(Freq.) & Pct. & 111(Freq.) & Pct. & Total mortalities \% mortality \\
\hline Control & 0 & 0 & 0 & 0 & 0 & 0 & 0 & 0 \\
7.5 & 3 & 30 & 2 & 20 & 2 & 20 & 8 & 26.7 \\
15 & 5 & 50 & 4 & 40 & 2 & 20 & 11 & 36.7 \\
20 & 5 & 50 & 4 & 40 & 4 & 40 & 13 & 43.3 \\
50 & 5 & 50 & 6 & 60 & 8 & 50 & 19 & 63.3 \\
75 & 9 & 90 & 7 & 70 & 9 & 90 & 25 & 83.3 \\
\hline
\end{tabular}


Amusat et al.: Toxicity Assessment of African Locust Bean Effluents on Agricultural Soil

Table 6: Number of death at 96 hours for Temidire effluent

\begin{tabular}{|c|cccccc|cc|}
\hline & \multicolumn{7}{|c|}{ Replicaties } & \\
Conc. of effluent (\%) & 1(Freq.) & Pct. & 11 (Freq.) & Pct. & 111 (Freq.) & Pct. & Total mortalities \% mortality \\
\hline Control & 0 & 0 & 0 & 0 & 0 & 0 & 0 & 0 \\
7.5 & 3 & 30 & 4 & 40 & 4 & 40 & 11 & 36.7 \\
15 & 6 & 60 & 3 & 30 & 5 & 50 & 14 & 46.7 \\
20 & 5 & 50 & 6 & 60 & 4 & 40 & 15 & 50 \\
50 & 7 & 70 & 8 & 80 & 6 & 60 & 21 & 70 \\
75 & 8 & 80 & 8 & 80 & 10 & 100 & 25 & 83.3 \\
\hline
\end{tabular}

The toxicity of effluents on the fish were evaluated and $\mathrm{LC}_{50}$ was determined for 72 hours and 96 hours for both effluent by probit analysis. The significant increased in mortality was directly proportional to the increased in concentration of effluent (Fig. 3 \& 4). No mortality was recorded in the control.

Response of C. gariepinus to Jimba-Oja effluent the results revealed that 72 hours $\mathrm{LC}_{50}$ was $36 \%$ while 96 hours was $20 \%$ of the effluent (Fig. 3) and response for Temidire effluent at 72 hours of LC $_{50}$ was $30.1 \%$ while 96 hours was $20 \%$ (Fig. 4) and sublethal dose below $7.5 \%$ for both effluent. The low motility rate at $7.5 \%$ and $15 \%$ concentration of effluents, this is of opinion that the exposure of fish to low concentration of toxicant do not extend to the stage of fatigue, rather they rapidly become adapted to the conditions of water, similar to the findings of Adewoye et al. (2005) but of different toxicant. The anomalous behaviour of the fish exposed to varying concentration of Africa locust bean effluents in this investigation gives suggestion of respiratory deficiency on the gills, and this finding is in agreement with results reported (Adewoye et al., 2005; Ayoola, 2008).

The $\mathrm{LC}_{50}$ tests (36\%:72 hours), (20\%: 96 hours) and (30.1\%: 72 hours), (20\%: 96 hours) concentration were obtained for Jimba-oja and Temidire respectively, which is an indication that at extremely low concentration of locust bean effluents released into water bodies may alter the physicochemical parameters of the water. This might in turn lead to extinction of the population size of the aquatic organisms.

The sharp increase in mortalities observed as the concentration of the test solution increased predict mortality to be a factor of concentration and this explains the discrepancy observed in the tests. This is similar to the observation of Adewoye and Fawole (2002a and b) that mortality rates increased over a small increase in concentration of cassava effluent. 


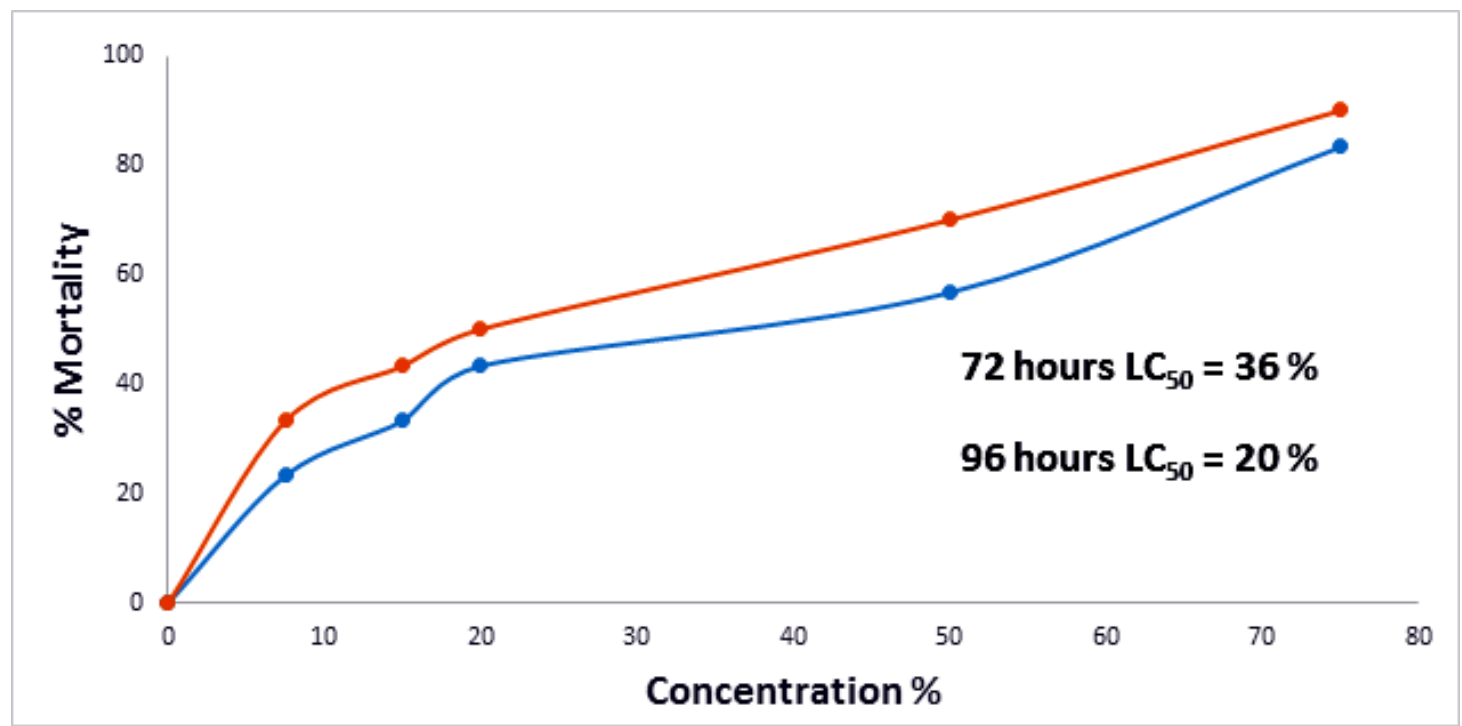

Fig. 3: Two weeks $\mathrm{LC}_{50}$ Clarias gariepinus at varying concentration of locust bean effluent from Jimba-oja.

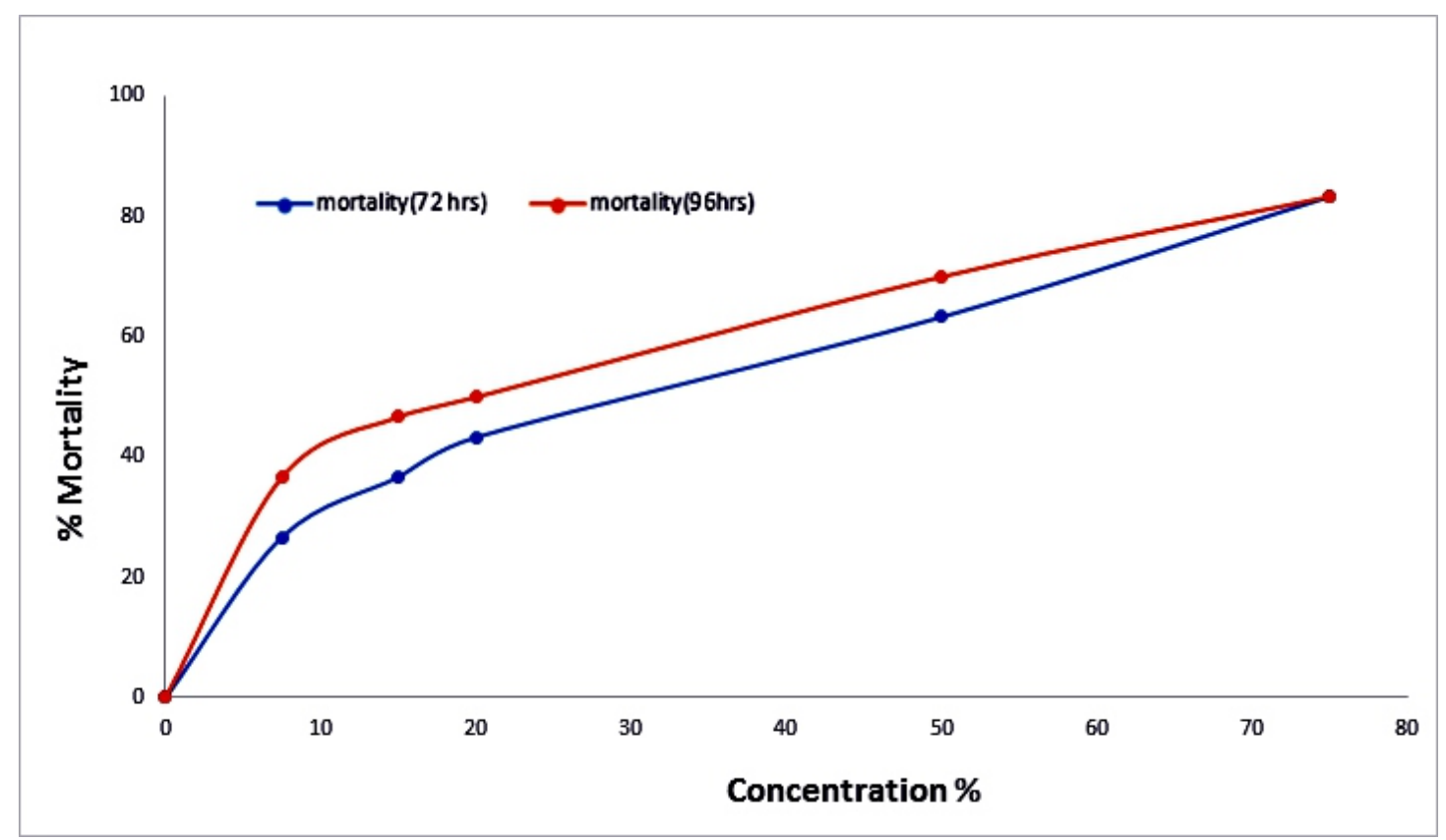

Fig. 4: Two weeks $\mathrm{LC}_{50}$ Clarias gariepinus at varying concentration of locust bean effluent from Temidire.

\section{CONCLUSION}

This investigation established that agricultural soil surrounding African locust bean processing centre was impacted destructively by considering the physic-ochemical parameters of the effluent and chemical properties of the soil evaluated from the two processing centers. Bioaccumulation of inorganic substances evaluated from the soil could lead to plant uptake at high concentrations greater than permissible limit which may result in a great health risk to humans being at the top to foodchain.

On the other hand, exposure of Parkia biglobosa effluent to Clarias gariepinus resulted in significant behavioural alterations of the fish. The results showed that effluents from the two locations at low concentrations of $7.5 \%$ were toxic. Consequently, it is pertinent to treat this effluent before being released to the environment 
in order to safe agricultural soils and aquatic habitat.

\section{REFERENCES}

Adewoye, S.O. and Fawole, O.O. 2002a. Acute toxicity of soap and detergent effluent to fresh water Clarias gariepinus fingerlings. African Journal of Science (In press).

Adewoye, S.O. and Fawole, O.O. 2002b. Bioconce nitration of metals in the tissue of Clarias gariepinus fingerlings exposed to lethal concentration of cassava wastewaters. World Journal of Biotechnology, 1(3): 2 (In press).

Adewoye, S. O, Fawole, O. O, Owolabi, O. D. and Omotosho, J. S. 2005. Toxicity of Cassava wastewater effluents to Africa Catfish Clarias gariepinus (Burchell, 1822). Sineti Ethiopian Journal of science, 28(2):189194

Akintobi, O. A., Bamkefa, B. A., Adejuwon, A. O. and Fagbola, T. M. 2016. Phytochemical analysis and antimicrobial evaluation of the extracts of the Root Bark and Rachis of Parkia biglobosa (Jacq.) Benth. on some human Pathogens. E3 Journal of Scientific Research. 4(1) 001-010, ISSN: 2276-9897.

Alabi, D. A., Akinsulire, O. R. and Sanyaolu, M. A. 2005. Quantitative determination of chemical and nutritional composition of Parkia biglobosa (Jacq.) Benth. African Journal of Biotechnology. 4 (8) 812-815.

Amusat, M. A., Taiwo, A. M., Ogundele, O. M. and Ademiluyi, Y. S. 2018. The Impacts of Industrial Effluent Discharge on Agricultural Fields. International Journal of Contemporary Research and Review, ISSN 0976-4852, (9)6:20240-20245.

Ayoola, S. O. (2008). Histopathological effects of glyphosate on juvenile African catfish (Clarias gariepinus). American-Eurasian Journal of Agricultural and Environmental Science, 4(3):362-367.

Bonkoungou, E. G. 1986. Monographic Study of NereParkia biglobosa (Jacq) Benth (Leguminosae, mimosoideae). Burkina Faso, Institute of Research Biology and Tropical Ecology, National Center for Scientific and Technological Research,
Ministry of Higher Education and Scientific Research (In Pres).

Das, P., Samantaray, S. and Rout, G. R. 1997. Studies on cadmium toxicity in plants: $a$ review of Environmental Pollution. 98(1):29-36.

Dike, E. N. and Odunfa, S. A. 2003. Microbiological and biochemical evaluation of a fermented soyabean product-soyadawadawa. Journal of Food Science Technology, 40: 606-610.

Dutch target and intervention values: 2000 (the new Dutch list) [Internet]. Delft, Netherlands: Dutch Standardization Institute; 2000 Feb 4; [cited 2015 August 27 ]. Available from:http://www.esdat.com.Au/Envir onmental\%20Standards/Dutch/annexS I2000Dutch\%20Environmental\%20St andards.pd.

Elemo, G. N., Elemo, B. O., Oladunmoye, O. O. and Erukainure, O.L. 2011. Comprehensive investigation into the nutritional composition of dehulled and defatted African locust bean seed (Parkia biglobosa). African Journal of Plant Science, 5 (5): 291-295.

Fafioye, O. O., Fagade, S. O. and Adebisi, A. A. (2005). Toxicity of Raphia vinifera, P.beauv fruit extracts on biochemical composition of Nile Tilapia (Oreochromis niloticus, Trewavas). Biokemistri, 17:137-42.

Faruk, O. S., Nazin, S. M. and Kara, S. M. 2006. Monitoring of Cadmium and Micronutrients in spices commonly consumed in Turkey. Research Journal of Agricultural and Biological Science, 2: 223-226.

Henry, U. I., Egbere, O. J., Henry, M. U., Lawal, I. H. and Ibrahim, I. I. Heavy metals content in fadama soils, root, leaf and seed of African locust bean tree (Parkia biglobosa) along the river Dilimi in Jos north local government area of Plateau state, Nigeria. International Journal of Agronomy and Agricultural Research, ISSN: 2223-7054, 9(4):36-43.

Karnataka State Pollution Control Board. 2002. 
Water quality monitoring of lakes in and around Bangalore city, Bangalore, 2: 1-8.

Odeyemi, O. O., Owoade, R. A. and Akinjurelere, R., 2000. Toxicity and population suppressions effects (Parkia clappertoninam) and dried fish pests (Dermentes maculated) and Necrobia rufipes. Global Journal of pure applied science, 6:191-193.

Ojewumi, M. E., Omoleye, A. J. and Ajayi, A. A. 2016b.The study of the effect of moisture content on the biochemical deterioration of stored fermented seeds. Open Journal of Engineer Research and Technology,
$1: 14-22$.

Olaniyi, C. O. and Salau, B. A. 2013. Effect of Pawpaw (Carica Papaya) Leave Meal on the Growth Performance and Blood Profile of African Cat Fish. Transnational Journal of Science and Technology 3(7): 1-7.

Yusuff, R. O. and Sonibare, J. A. 2004. Characterization of textile industries effluents in Kaduna, Nigeria and pollution implications. Global Nest: International Journal, 3:212-221.

WHO. 1996. Permissible limits of heavy metals in soil and plants (Geneva: World Health Organization), Switzerland. 